\title{
Stock Market Screening: An Analogical Study on Conventional and Shariah-Compliant Stock Markets
}

\author{
Gholamreza Zandi ${ }^{1}$, Dzuljastri Abdul Razak ${ }^{2}$ \& Nur Hidayah Hussin ${ }^{2}$ \\ ${ }^{1}$ Graduate School of Business, SEGi University, Malaysia \\ ${ }^{2}$ Department of Finance, International Islamic University Malaysia, Malaysia \\ Correspondence: Gholamreza Zandi, Graduate School of Business, SEGi University, Kuala Lumpur, 47810, \\ Malaysia. Tel: 60-3-6145-3148. E-mail: zandi@segi.edu.my
}

$\begin{array}{lr}\text { Received: August 18, } 2014 & \text { Accepted: September 10, } 2014 \quad \text { Online Published: October 30, } 2014 \\ \text { doi:10.5539/ass.v10n22p270 } & \text { URL: http://dx.doi.org/10.5539/ass.v10n22p270 }\end{array}$

\begin{abstract}
Benchmarking Shariah-Compliant stocks listed in Bursa Malaysia, this paper examined whether the stocks which are approved by SACSC are also considered as Shariah-Compliant under International Indices. 35 top Shariah-Compliant stocks listed in Bursa Malaysia were examined against four stock screening criteria of DJIM, MSCI, FTSE and S\&P. Due to the differences in stock screening criteria, the factors evaluated that lead to variances in Shariah-Compliant status for a particular stock. The results from the test indicate that Shariah-Compliant stocks listed in Bursa Malaysia are not necessarily Shariah-Compliant stocks in the four Indices of DJIM, MSCI, FTSE and S\&P. The high debt and low market capitalization are the main factors of dropping the Malaysian Shariah-Compliant stocks by the four Indices. The three stages of screening which carry the most Islamic stock screening process include screening on industry, income statement and balance sheet.
\end{abstract}

Keywords: Shariah-compliant, market capitalization, indices, screening, industry

\section{Introduction}

\subsection{Research Problem}

In every country, equity market is very important as one of economic generation mediums. Due to that fact, efficiency and effectiveness in equity market system must be properly installed. Screening methodology is one of the essential elements that need to be improved from time to time in order to ensure that the equity market could generate the most possible return to the economy as a whole. This is because, based on screening criteria, stocks are classified as Shariah or non-Shariah compliant stocks. The status of a particular stock would affect investors' decision particularly Muslim investors. Definitely, Shariah-Compliant stocks would cater a wider range of investors, thus resulting in higher demand, given that the stocks are performing well. As compared to non-Shariah stocks, even though the stocks are giving up higher return, Muslim investors cannot buy and thus it might slow down the trading of the stocks. The equities which are in compliance with the Shariah Investment Requirements perform better than conventional equities especially when markets are down. The better performance of Islamic Compliance Companies can stem from the Shari'ah screening criteria which prohibits any involvement in shares of those companies that are excessively leveraged and/or engaged in lending activities (Ashraf \& Mohammad, 2014).

Muslim investors in the current arena are very much concerned on halal income earned. As such, the Islamic finance system should be geared in such a way that could provide confidence towards these investors. In reference to equity market, the most general business activity is stock trading. In buying and selling stocks, it is crucial to ensure that the stocks are classified as Shariah compliant. With the existence of different stock screening, it might generally affect the confidence of the investors in taking part in this business activity. Furthermore, current studies have yet to cater all these five screening methodologies and thus the conclusion of which factors that determine the different status are to be studied in this paper.

Some prominent scholars have suggested that there is a need to standardize the screening methodology in order to obtain global Shariah stocks. By having a standard stock screening methodology, investors from all over the world can trade without the need to check the compliant status for every stock exchange. This will encourage foreign investments and thus expanding the world economy. Nonetheless, in current system, each stock 
screening provider has its own developed methodology which differs with each other. Due to the differences, this paper would like to discuss the similarities and differences and examine the number of Shariah stock compliance approved by SACSC that are also approved by four different Indices namely Dow-Jones Islamic World Market (DJIM), Morgan-Stanly Compliance Islamic Index (MSCI), FTSE Shariah Index (FTSE), and Standard and Poor Shariah Index (S\&P).

The differences in the methodology have triggered the idea of this study. However, based on articles that are available, researches were done mostly in regarding to the comparison of performances, risks, and such between conventional and Islamic equities but rarely in examining Shariah screening criterion. Due to this, it is hoped that this research will bring another strong impact on the mentioned matter. In addition to that, this study is done with a belief that Shariah status for a particular stock is very important as it reflects the faith in the Almighty God. It is clear that Usury is prohibited in Islam and human must obtain the growth of their wealth in a rightful manner. This study will focus on Usury as it is reflected by debt and liquidity nature of business. Because of its crucial element in the spirit of Islam, this study will examine whether the compliant status of the Shariah-Compliant companies under Securities Commission are also holding Shariah status after benchmarking with Islamic screening criteria practiced by individual International Index.

Much research are done in analysing the Shariah stock screening (Nathie, 2008; Haron \& Nursofiza, 2008; Dusuki \& Abdullah, 2009; Jamal et al., 2010; Shamsuddin, 2014; Ashraf \& Mohammad, 2014) but in this study, we extended analyses to the four International Stock Screening Providers of DJIM, FTSE, MSCI and S\&P. Shariah-Compliant stocks listed in Bursa Malaysia are examined against these four different benchmarks. This research aimed on information of benchmark level of debt and liquidity of the companies considered as Shariah-Compliant stocks. In addition to that, since the stocks are analysed for each Index, companies that are interested to expand business outside Malaysia and concern on Shariah-Compliant status can use the finding to forecast which stock exchange they can register in.

\section{Literature Review}

Islamic finance is currently an emerging science and well-developing area of study. The significance of Islamic finance is due to many people beliefs that it can be the best alternative for conventional finance. In order to provide solution to the weakness in the conventional banking and financial system, many people are becoming alert to the resilience of Islamic finance as a feasible alternative. In addition, Islamic finance is deemed to operate in the line with the Shariah.

Shariah is a broad term to describe a system that consists of every aspect of livelihood. It includes ethics and values of personal, social, political, economics, and intellectual (Dusuki \& Abdullah, 2009). All practices in life must be accordance to the sources of Islamic Law (Shariah) which are the Quran and the Sunnah (the Prophet's traditions). These traditions are considered normative actions which then will be passed on from one generation to another (ISRA, 2011).

As the world gets older, many new inquiries, interrogatories, issues and problems emerged at later time. Given that the two main sources have not clearly covered the wider scope of life and thus the justifications and answers are unavailable. In order to have solutions to the problems, particularly contemporary solutions, other seven sources are authorized to be considered as sources of Shariah. The sources are, written in order, Ijma, Qiyas (Analogical Deductions), Istihsan, Istishab, Maslahah Mursalah (Public Interest), Sadd al-Dhara'I (Blocking the Means to an Evil), and 'Urf (Customary Practices) (ISRA, 2011).

It is emphasized in Dusuki and Abdullah (2009), the deep understanding of Shariah requires the determination of its' comprehensive objectives "to allow flexibility, dynamics, and creativity in social policy." The flexibility, dynamics, and creativity in social policy are needed elements in facing further developments as different timeframes would require different rulings due to the upcoming needs of people. The determinations of its' comprehensive objectives have given a signal to change Shariah solutions from time to time. However, the changes must be approved by Shariah scholars (Jamal et al., 2010).

After a comprehensive discussion on Shariah, it is undoubtedly to agree that methodology used in Islamic finance is changeable over time. In addition, the methodology can also be different from one particular scholar to another due to scholars' different background and area of living. In some cases, their organizations' objectives do influence the decisions and it is acceptable as long as the decision does comply with Shariah.

One of the methodologies which are a concern of this study is Shariah stock screening. In current Islamic finance system, many Index providers created and marketed (Haron \& Nursofiza, 2008). The providers can be Index providers as well as country's Shariah Advisory Council. In this study, five Shariah stock screening providers 
will be discussed namely Dow-Jones Islamic World Index (DJIM), Morgan-Stanly Compliance Islamic Index (MSCI), Financial-Times Stock Exchange Shariah Index (FTSE), Standard \& Poor Shariah Index (S\&P), and Shariah Advisory Council of Securities Commission (SACSC). The Shariah stock screening is essential in order to classify stocks to be listed in Indices. The Dow Jones Islamic Market indices (DJIMI) are constructed by screening out stocks that are incompatible with Islam's prohibition of interest and certain lines of business. However, as a blunt instrument, the interest rate can affect discounted cash flows of any firm, even a firm with no financial leverage (Shamsuddin, 2014).

These Shariah stock screening providers have come out with different kinds of screening methodologies which will be explained in the next chapter. The issue that might arise from the differences is which one of these methodologies is the best or the most 'Islamic' way of conducting Shariah stock screening. Since these methodologies might be changed over the time, the effect on the stocks' performance could be one of the determinants to modify the screening methodologies because the change in the benchmarks will result in the change in asset universe. Asset universe refers to stocks that are listed in the Index. However, according to Nathie (2008) equity market does not be influenced by the change of compliant status. Yet, as Islamic finance has gained much awareness from public including Muslim investors, the compliant status has become one of the indicators in deciding the purchase of the stocks.

According to a study on Islamic Equity Indices from year 2000 to 2012 by Ashraf and Mohammad (2014), there was not seen any abnormal returns related to the Islamic Equity Indices. The less systematic risk in comparison with their benchmark representing that the better performance stems from the systematic risk that each investment presumes with respect to their benchmark.

By having said that, the quantity of stocks demanded by Muslim investors will affect the movement of the demand and supply and thus resulting in price determination. One situation that can explain this is when in the case of the stocks turn into non-compliant stocks; Muslim investors have to sell off the stocks (Dusuki \& Abozaid, 2007). It increases the supply for the stocks and if given that the demand does not change, the price of the stocks will go down. This situation shows that Shariah-Compliant status is one of significant determinations of the stock performance.

Due to its importance, this study aims to dig more on Shariah screening issues. The approach of this study will include Shariah-Compliant stocks approved by SACSC listed in Bursa Malaysia as it will be used as benchmark to calculate the compliant status from these four methodologies. The main difference between SACSC and these four screening methodologies are the use of balance sheet as part of the screening benchmark (Alhabshi, 2008). Balance sheet items particularly liquidity and leverage are not part of the screening in SACSC as their focus mainly on prohibited income i.e. prohibited income earned by subsidiaries or associates (Huzairi, 2009).

This paper will study each screening methodology and explore their differences and similarities. As far as the study is concerned, prohibited income benchmark will not be tested as it is assumed that as long as these stocks have been considered as Shariah compliant under SACSC, thus, prohibited income will not be an issue since it has been filtered out. In addition, the different status of the same stock will also be analyzed and discussed. This study will also conclude the factors of differences in Shariah-Compliant status among these Indices. Subsequently, the most 'Islamic' screening methodology will be indicated.

\section{Research Methods}

This study is exploratory and descriptive in nature and based on a study by Rahman et al., (2008) regarding Islamic norms for stock screening of the Bursa Malaysia Islamic Index and the Dow Jones Islamic Market Index.

The differences between SACSC and International Indices are the two financial measures which are liquidity and debt ratio. In addition, timeline research will be done in order to measure the consistency of the compliant status. The Shariah-Compliant stocks listed for three years under Securities Commission Malaysia from 2009-2011 constituted our sample.

\subsection{Sampling and Data Collection}

The population of the study consisted of 839 Shariah complaint companies under Securities Commission as at November 2011. To rationalize the study, top 100 Shariah compliant companies are filtered. The top 100 companies are chosen to ensure the relevancy of these companies to expand their business internationally. In addition to choosing the 100 companies, in order to enhance the relevancy of expanding businesses globally, companies are filtered by removing companies that are not consistently Shariah-Compliant for three years. After removing companies that did not have complete information and were not Shariah-complaint stocks for the three years, the final sample is 35 companies with large market capitalization out of 100 large market capitalization 
companies. The selection is based on available data for the financial statement as well as the listing in Bursa Malaysia from 2009-2011. After the sample was determined, the stocks were tested against the benchmarks and compliant statuses for each Index obtained. Furthermore, the factors behind the non-Shariah compliant were analysed based on the testing results. The financial measures are calculated based on each Index Shariah Stock Screening Methodology. It is summarized as per Table 1.

All balance sheets data are gathered by using data stream provided by the University Technology Mara (UiTM)'s library. For market capitalization, monthly prices from 2007 to 2011 are compiled and it was then averaged according to the ratios i.e. 36 months and 24 months.

Table 1. Financial measures of DJIM, MSCI, FTSE \& S\&P

\begin{tabular}{|c|c|c|c|c|}
\hline & $\begin{array}{l}\text { Dow Jones Islamic } \\
\text { Market }\end{array}$ & $\begin{array}{l}\text { Morgan-Stanly } \\
\text { Compliance Islamic }\end{array}$ & $\begin{array}{l}\text { Financial Times Stock } \\
\text { Exchange }\end{array}$ & $\begin{array}{l}\text { Standard \& } \\
\text { Poor }\end{array}$ \\
\hline \multirow[b]{2}{*}{$\begin{array}{l}\text { Liquidity } \\
\text { Ratios }\end{array}$} & $\begin{array}{l}\text { Acc Rec/24Mth MA } \\
\text { Market Cap. }<33 \%\end{array}$ & $\begin{array}{l}\text { Total Cash }+ \text { Account } \\
\text { Receivables/Total Assets }< \\
33.33 \%\end{array}$ & $\begin{array}{l}\text { Acc } \operatorname{Rec}+\text { Cash/Total } \\
\text { Asset }<50 \%\end{array}$ & $\begin{array}{lr}\text { Acc } & \text { Rec } / 36 \\
\text { Mth } & \text { MA } \\
\text { Market } & \text { Cap } \\
<49 \% & \end{array}$ \\
\hline & $\begin{array}{l}\text { Cash }+ \text { Int Bearing } \\
\text { Sec/24 Mth MA } \\
\text { Market Cap. }<33 \%\end{array}$ & $\begin{array}{l}\text { Cash }+ \text { Interest-Bearing } \\
\text { Sec/Total Assets }<33.33 \%\end{array}$ & $\begin{array}{l}\text { Cash }+ \text { Int } \text { Bearing } \\
\text { Sec/Total Assets }<33 \%\end{array}$ & $\begin{array}{l}\text { Cash }+ \text { Int } \\
\text { Bearing } \\
\text { Sec/36 Mth } \\
\text { MA Market } \\
\text { Cap. }<33 \%\end{array}$ \\
\hline Debt Ratio & $\begin{array}{l}\text { Total debt divided by } \\
\text { trailing } 24 \text {-month } \\
\text { average market } \\
\text { capitalization }<33 \%\end{array}$ & $\begin{array}{l}\text { Total Debt/Total Assets < } \\
33.33 \%\end{array}$ & $\begin{array}{l}\text { Total Debt/Total Asset }< \\
33 \%\end{array}$ & $\begin{array}{l}\text { Total } \\
\text { Debt/36 Mth } \\
\text { MA Market } \\
\text { Cap }<33 \%\end{array}$ \\
\hline
\end{tabular}

\section{Results and Findings}

The data finding will be presented into 3 years. Data presented determines the stocks' compliant for each year and the timeliness provides consistency of the compliant status. This is significant evidence where companies in the sample could use the consistency to measure their feasibility to be listed internationally by maintaining its capital structure and its liquidity level.

Table 2.

\begin{tabular}{|c|c|c|c|c|c|c|}
\hline & & DJIM & MSCI & FTSE & S\&P & \\
\hline \multirow{3}{*}{ Ann Joo } & 2009 & $\mathrm{X}$ & $\mathrm{X}$ & $\mathrm{X}$ & $\mathrm{X}$ & \multirow{3}{*}{$2009,2010 \& 2011$ NSC due to high debt } \\
\hline & 2010 & $\mathrm{X}$ & $\mathrm{X}$ & $\mathrm{X}$ & $\mathrm{X}$ & \\
\hline & 2011 & $\mathrm{X}$ & $\mathrm{X}$ & $\mathrm{X}$ & $\mathrm{X}$ & \\
\hline \multirow{3}{*}{$\begin{array}{l}\text { Bandar Raya } \\
\text { Development }\end{array}$} & 2009 & $\mathrm{X}$ & / & / & $\mathrm{X}$ & \multirow{3}{*}{$\begin{array}{l}2009,2010 \text { \& } 2011 \text { NSC due to low market } \\
\text { capitalization }\end{array}$} \\
\hline & 2010 & $\mathrm{X}$ & l & / & $\mathrm{X}$ & \\
\hline & 2011 & $\mathrm{X}$ & l & l & $\mathrm{X}$ & \\
\hline \multirow{3}{*}{ BIMB } & 2009 & $\mathrm{X}$ & l & / & $\mathrm{X}$ & \multirow{3}{*}{$\begin{array}{l}2009,2010 \text { \& } 2011 \text { NSC due low market } \\
\text { capitalization and high cash and } \\
\text { interest-bearing securities }\end{array}$} \\
\hline & 2010 & $\mathrm{X}$ & / & / & $\mathrm{X}$ & \\
\hline & 2011 & $\mathrm{X}$ & l & l & $\mathrm{X}$ & \\
\hline \multirow{3}{*}{ Dijaya } & 2009 & $\mathrm{X}$ & l & l & $\mathrm{X}$ & \multirow{3}{*}{$\begin{array}{l}2009 \& 2010 \text { NSC due to low capital market } \\
2011 \text { NSC due to high debt }\end{array}$} \\
\hline & 2010 & $\mathrm{X}$ & l & / & $\mathrm{X}$ & \\
\hline & 2011 & $\mathrm{X}$ & $\mathrm{X}$ & $\mathrm{X}$ & $\mathrm{X}$ & \\
\hline \multirow{3}{*}{ Duta Land } & 2009 & $\mathrm{X}$ & $\mathrm{X}$ & $\mathrm{X}$ & $\mathrm{X}$ & \multirow{3}{*}{$2009 \& 2010$ NSC due to high debt } \\
\hline & 2010 & $\mathrm{X}$ & $\mathrm{X}$ & $\mathrm{X}$ & $\mathrm{X}$ & \\
\hline & 2011 & $\mathrm{X}$ & l & / & $\mathrm{X}$ & \\
\hline Eastern \& Oriental & 2009 & $\mathrm{X}$ & $\mathrm{X}$ & $\mathrm{X}$ & $\mathrm{X}$ & $2009,2010 \& 2011$ NSC due to high debt \\
\hline
\end{tabular}




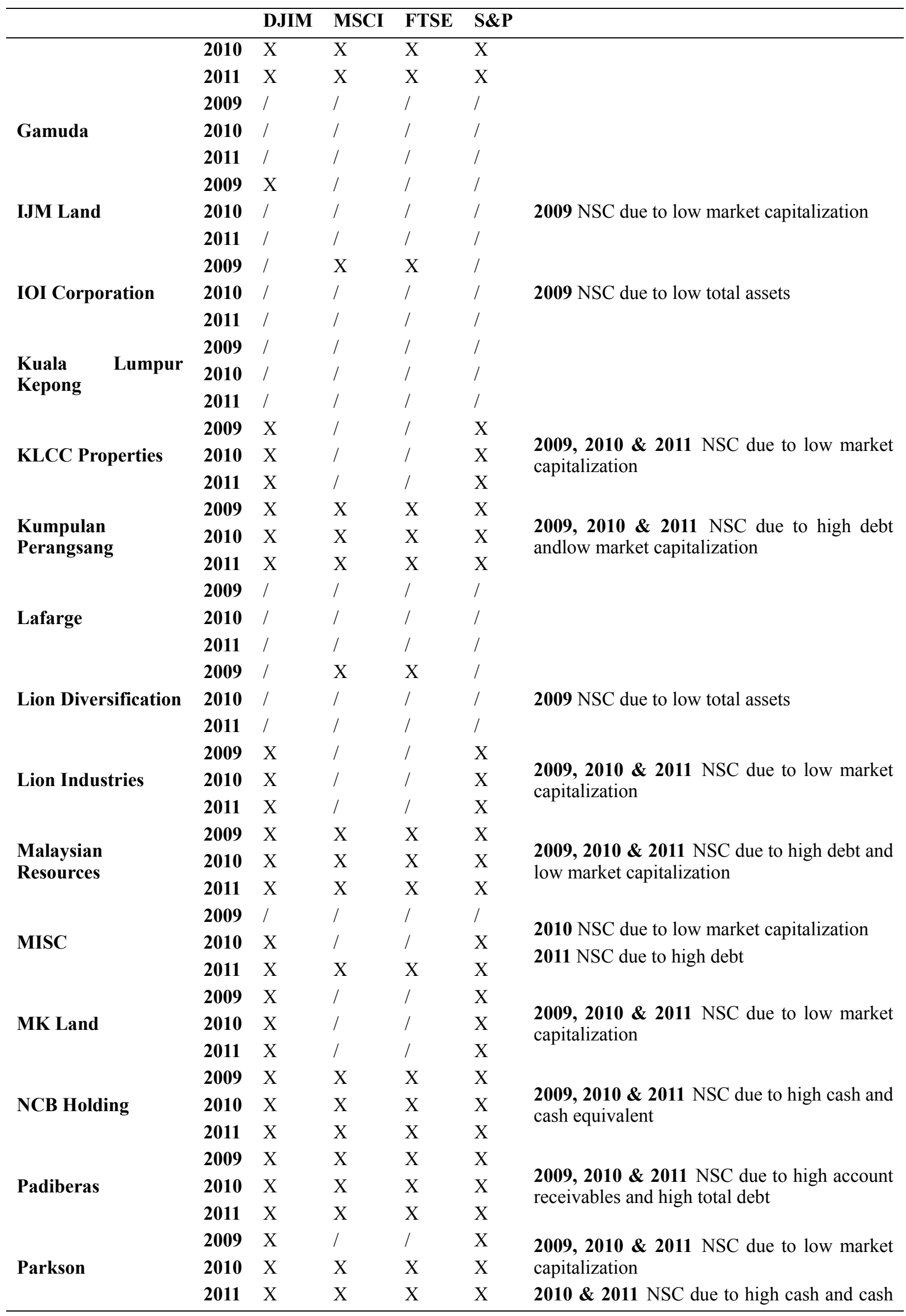




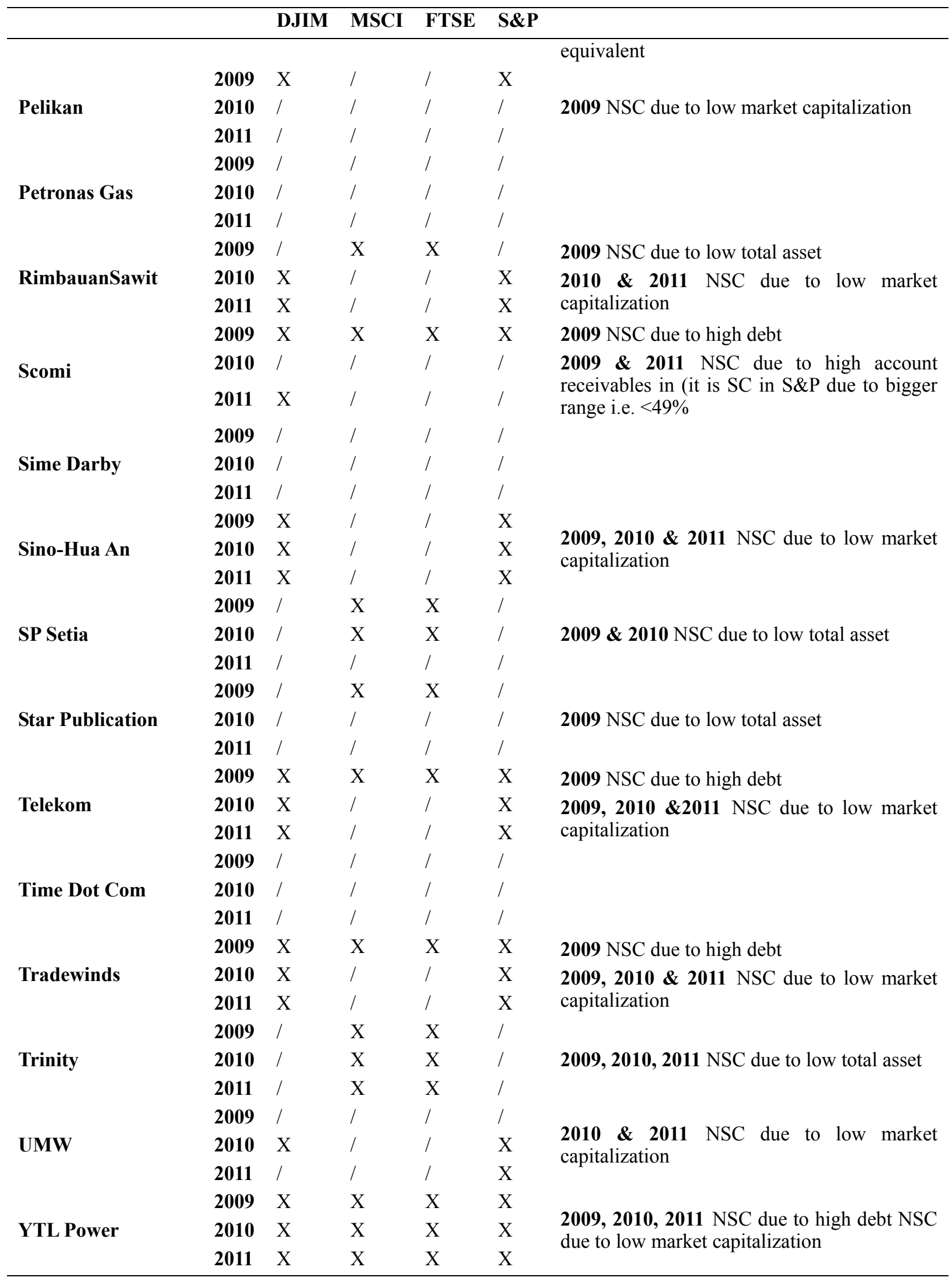

Note: SC is referred as Shariah-Compliant, NSC is referred as Non-Shariah Compliant. 
After a detail computation of the ratios, the final conclusion is derived and presented in the table above. Each company is tested against ratios of each Index for that Index. The tick (/) represents that the company is Shariah compliant while the cross $(\mathrm{X})$ mark represents non-Shariah compliant. In addition to the test on Shariah compliant, the factors that cause the non-Shariah compliant are also analysed.

Table 3. Number of Shariah-compliant stocks

\begin{tabular}{lllllll}
\hline Index & $\mathbf{2 0 0 9}$ & $\mathbf{\%}$ & $\mathbf{2 0 1 0}$ & $\mathbf{\%}$ & $\mathbf{2 0 1 1}$ & $\mathbf{\%}$ \\
\hline DJIM & 14 & $40.00 \%$ & 14 & $40.00 \%$ & 14 & $40.00 \%$ \\
MSCI & 18 & $51.43 \%$ & 24 & $68.57 \%$ & 24 & $68.57 \%$ \\
FTSE & 18 & $51.43 \%$ & 24 & $68.57 \%$ & 24 & $68.57 \%$ \\
S\&P & 17 & $48.57 \%$ & 14 & $40.00 \%$ & 14 & $40.00 \%$ \\
Sample: 35 & & & & & & \\
\hline
\end{tabular}

The Table 3 represents the number and percentage of Shariah compliant stocks of these four Indices as opposed to companies listed in Bursa Malaysia according to years. Based on the table II, there is consistency of number of Shariah compliant stocks in each Index. At most, $68.57 \%$ of the companies are considered as Shariah compliant under MSCI and FTSE while at most only $40 \%$ and $48.57 \%$ of the companies are considered as Shariah compliant under DJIM and S\&P respectively. It does reflect that if these companies would like to expand their business outside Malaysia and be listed as Shariah compliant stock, they could retain the liquidity and debt ratio.

The companies are shown in the Table 4.

Table 4. Sample of Shariah-compliant stocks

Consistently Shariah Compliant Stocks in 2009, 2010 \& 2011

\begin{tabular}{|c|c|c|c|c|c|}
\hline & & DJIM & MSCI & FTSE & $\mathbf{S \& P}$ \\
\hline \multirow{20}{*}{$\begin{array}{l}\text { Consistently Shariah Compliant Stocks in 2009, } \\
2010 \text { \& } 2011\end{array}$} & $\begin{array}{ll}\text { Bandar } & \text { Raya } \\
\text { Development } & \end{array}$ & & 1 & 1 & \\
\hline & BIMB & & 1 & 1 & \\
\hline & Gamuda & l & l & l & l \\
\hline & IJM Land & & l & l & l \\
\hline & IOI Corporation & l & & & l \\
\hline & Kuala Lumpur Kepong & l & I & l & l \\
\hline & KLCC Properties & & l & l & \\
\hline & Lafarge & l & l & l & l \\
\hline & Lion Diversification & l & & & l \\
\hline & Lion Industry & & I & l & \\
\hline & MK Land & & l & l & \\
\hline & Pelikan & & I & l & \\
\hline & Petronas Gas & l & l & l & l \\
\hline & Sime Darby & l & I & l & l \\
\hline & SP Setia & I & & & I \\
\hline & Star Publication & l & & & / \\
\hline & Sino-Hua An & & l & l & \\
\hline & Time Dot Com & I & l & l & l \\
\hline & Trinity & l & & & l \\
\hline & UMW & & l & l & \\
\hline Total & & 11 & 15 & 15 & 12 \\
\hline
\end{tabular}


From the Table 4, there are 11 companies that can register in DJIM, 15 in MSCI and FTSE, and 12 in S\&P. Thus, by indicating which Index they could register, it provides them a signal of the ability in expanding business outside Malaysia. These companies could also use the finding to choose which stock exchange they could register. Furthermore, there are 6 companies classified as Shariah compliant consistently in three years in all International Indices. The companies are Gamuda Berhad, IOI Corporation Berhad, Lion Diversified Holdings, Petronas Gas Berhad and Time Dotcom Berhad. These companies are the most possible stocks to be globally accepted as Shariah compliant stocks.

The differences in the percentage of Shariah compliant stocks can be explained by having different divisors. MSCI and FTSE use total asset as divisor while the other Indices use market capitalization as divisor. As proven in the table above, total asset could be a better divisor in measuring the ratios since it does include more Shariah complaint stocks. Moreover, it has no direct inevitably effect from the change of share price, thus resulting in a stable asset universe in the Index.

On the other side of the issue, despite from using the same divisor between DJIM and S\&P, it is proven that different use of trailing month resulted in different numbers of Shariah stocks as shown in the table, S\&P holds bigger number of stocks as compared to DJIM of $48 \%$ and $40 \%$ respectively due to the reason that S\&P uses 36 trailing-month market capitalization as compared to DJIM which uses 24 trailing-month market capitalization. As mentioned previously, the longer the tailing month would result in bigger divisor thus reducing the ratios.

Table 5. Factors affecting non-Shariah compliant

\begin{tabular}{lllll}
\hline Factors & $\mathbf{2 0 0 9}$ & $\mathbf{2 0 1 0}$ & $\mathbf{2 0 1 1}$ & Total \\
\hline High Debt & 9 & 6 & 7 & 22 \\
Low Market Capitalization & 10 & 12 & 11 & 33 \\
Low Total Asset & 6 & 2 & 1 & 9 \\
High Cash and Interest Bearing Securities & 1 & 2 & 3 & 6 \\
High Account Receivable & 1 & 1 & 1 & 3 \\
\hline
\end{tabular}

Apart from finding on the compliant status in three years, another analysis that can be synthesized from the research is the factors that are affecting the non-Shariah compliant status. From the observation and as summarized in the Table 5, the most frequent factor that affects the non-compliant status is due to low market capitalization. It is consistent with the result of lesser number of Shariah compliant stocks under DJIM and S\&P as opposed to MSCI and FTSE. The second factor that affects the non-compliant status is due to high debt. This explains the reason of not all Shariah complaint companies under KLSE are Shariah compliant under other Indices. Other three insignificant factors that affect the non-Shariah compliant are low total assets, high cash and interest bearing securities, and high account receivables.

The Islamic sector portfolios have less interest rate risk exposure compared to the Dow Jones World sector indices, their mainstream counterparts, in terms of the sensitivity of the DJIMI return to changes in level, slope and curvature of the interest rate term structure (Shamsuddin, 2014).

\section{Discussion and Conclusion}

The Shariah-Compliant stocks under SACSC are also considered as Shariah-Compliant under International Indices if they follow the ratio test. Based on the ratio test in 2009, 14 and 17companies are considered as Shariah-Compliant stocks under DJIM and S\&P respectively, while 24 companies are Shariah-Compliant stocks under both FTSE and MSCI. In 2010, 14 companies are Shariah-Compliant under DJIM and S\&P and 24 companies in FTSE and MSCI. In 2011, the number of Shariah-Compliant stocks is maintained for each Index i.e. 14 companies in DJIM and S\&P and 24 companies in FTSE \&MSCI. This indicates that the FTSE and MSCI have resulted in higher number of Shariah-Compliant stocks as compared to DJIM and S\&P.

After determining the status of each company, the factors that lead to non-Shariah compliant were examined. From the results, the highest factor that contributes to non-Shariah compliant is low market capitalization. It reflects the lesser number of Shariah-Compliant stocks in DJIM and S\&P as a result of using market capitalization as their divisors.

Furthermore, the second highest factor that affects the compliant status is high debt. Due to high debt, many companies were unable to pass the benchmark used in each Index. Because of this, not all companies listed in 
Bursa Malaysia as Shariah stocks were also considered as Shariah stocks in International Indices. Apart from these two significant factors, the other three insignificant causes are low total assets, high cash and interest-bearing securities as well as high account receivables.

The most 'Islamic' stock screening methodology is to have 3 stages of screening. For the first stage, industry screening is a must and it seems not much controversial on the issue. All screening providers have included the first stage in their screening. The second stage is screening on income statement. This is also important to ensure that the company's income is generated through Halal activities. After passing the screening, the last stage is to screen the balance sheet. In this case, two controversial items which are debt and liquidity should be included as part of the screening. The ratio should generally agree to be less than $33 \%$.

After a complete investigation in this study, it is firmed that Securities Commission's benchmarks are developed in order to provide high number of Shariah compliant stocks listed in Bursa Malaysia. The reason behind that is to encourage Muslim investors to participate in equity market. The involvement of Muslim investors in equity market is important since it increases the number of traders as well as playmaker in the industry. Consequently, the equity market moves. From the result, is it proven that $\mathrm{SC}$ has not taken balance sheet as part of its screening since it will downsize the number of Shariah-Compliant stocks. In addition, taken the issue into consideration, a high number of Shariah-Compliant stocks are needed due to the fact that has been mentioned above.

Nonetheless, there are many other benefits that can be barely seen when debt and liquidity ratio are included as part of the screening. By having such ratios as part of screening, the integrity of Islamic stocks will be strengthened. Consequently, it will increase investors' confidence in Islamic finance. This is very crucial since in this current time, there are strong understanding and awareness among investors as well as public as a whole. Furthermore, when debt is taken as part of screening, companies will tend to avoid taking financing from banks. Generally, debt would bring bad impacts in the economy when it has to be paid with an extra amount because money will be created out of nothing to back it up. When it happens, no real economy is generated and only fiat money is created to pay the debt and as a result, inflation will occur.

Given a simple scenario mentioned above, it is crucial for debt ratio to be included as part of the screening as subsequently banks, entrepreneurs and companies will be encouraged to get involved in profit and loss sharing investments. This will cultivate and instil the essence of 'real' Islamic finance where partnership or profit and loss sharing are highly recommended in the system. In addition, according to Nisar and Khatkhatay (2007), equity market is very close to the genuine Islamic profit-sharing investments. Hence, the inclusive of debt ratio is the screening will generate a better Islamic finance system as well as the economic system as a whole. Apart from debt ratio, liquidity ratio is also significant to be included in the screening benchmark. This is because companies will have a better collection on account receivables. The lesser amounts of account receivables generate lesser liquidity ratios. As such, companies will have an opportunity to pass the screening. In addition to that, by investing the money in proper investment channels, the economy will move. Due to that, companies will avoid holding much money and thus they will have the chance to pass the liquidity screening. Since the inclusion of interest-bearing securities is part of the screening, companies will avoid investing in such investments and in return, they will invest in Islamic securities and hence, the Islamic finance will develop further. In discussion the ratios, one issue to be highlighted is the basis. As mentioned in the previous section, DJIM and S\&P use market capitalization as the basis of the ratios, while MSCI and FTSE use total assets as the basis. According to the finding, MSCI and FTSE have resulted higher number of Shariah-Compliant stocks as compared to DJIM and S\&P. Total assets is a better basis due to the reason that it does not be reflected by market forces. As compared to market capitalization, it is exposed to market condition as it can change in a split second. By having total assets as the basis, the asset universe will be more stable and appropriate. Nonetheless, those who are against total assets mentioned that the balance sheet items are not appropriate due to the fact that accounting could be manipulated and the availability of the figures could only be known at the end of the year. However, total assets will be the best basis because of its stability. In addition, to argue the manipulation of accounting, it could not be true because procedurally, before the financial statement is published, companies have to send the completed financial statement for auditing. Once auditing is done, the credibility of financial statement would increase and it is a practice in most of the companies that financial statement is prepared periodically. Due to this, there is no reason that the financial statement is not available at the time of screening. For example in Securities Commission, the periodic screenings are in May and November and since Securities Commission will have the authority to request for the financial statements, total assets is the most practical basis to be used in the screening ratios.

In a nutshell, SACSC may want to redevelop the screening methodology by including the debt and liquidity ratios. By the inclusion of debt and liquidity ratio, Islamic finance could have been better in the future. In 
addition to that, total assets are a better basis as compared to market capitalization. Apart from advantages mentioned above, the use of total assets will eliminate the choice of trailing months. As DJIM and S\&P use different trailing months, it creates a gap in Shariah-Compliant status, thus reducing the credibility of Islamic stocks as well as destroying investors' perception on Islamic stocks. Hence, it is essential for Shariah stock screening providers to include debt and liquidity ratios a part from prohibited income.

\section{References}

Alhabshi, S. O. (2008). Stock Screening Process (Issue 20). International Centre for Education in Islamic Finance, RAM Bulletin.

Dawood, A., \& Nazeeruddin, M. (2014). Matching perception with the reality: Performance of Islamic equity investments. Pacific-Basin Finance Journal, 28, 175-189. http://dx.doi.org/10.1016/j.pacfin.2013.12.005

Dusuki, A. W., \& Abdullah, N. I. (2009). Maqasid al Shariah (Objective of Shariah) in the Islamic Capital Market: Special Focus on Equity Sukuk. ISRA Research Paper (No.5/2009).

Dusuki, A. W., \& Abozaid, A. (2007). A Critical Appraisal on the Challenges of Realizing Maqasid Al-Shariah in Islamic Banking and Finance. IIUM Journal of Economics and Management.

Haron, S., \& Nursofiza, W. (2008). Creating a Dynamic Islamic Capital Market. Islamic Capital Market, Products, Regulation \& Development. Islamic Development Bank, 23-32.

Huzairi, A. (2009). Stock Screening in Malaysia: Strict or Loose. IBBM Bulletin. (cek website)

ISRA. (2011). Islamic Financial System, Principles \& Operations. Kuala Lumpur: Pearson.

Jamal, J., Hambali, N., \& Ali, H. M. (2010). Islamic capital market and Shari'ah screening in Malaysia. International Research Symposium in Service Management.

Nathie, M. (2008). Embracing Islamic Investment in Australia Using the Malaysian Model: Challenges and Opportunity in The Challenges and Opportunities of Islam in the West: The Case of Australia conference conducted at Griffith University. Retrieved from http://www.griffith.edu.au/_data/assets/pdf_file/0017/ 66014/Magniid-Conference-Article.pdf

Nisar, S., \& Khatkhatay, M. H. (2007). Sharia-Compliant Equity Investments: An Assessment of Current Screening Norms. Islamic Economic Studies, 15(1), 47-67.

Rahman, A. A., Yahya, M. A., \& Nasir, M. H. M. (2008). Islamic norms for stock screening: A Comparison Between the Kuala Lumpur Stock Exchange Islamic Index and the Dow Jones Islamic Market Index. Retrieved from http://www.emeraldinsight.com/journals.htm?articleid=1881399\&show=abstract

Shamsuddin, A. (2014). Are Dow Jones Islamic Equity Indices Exposed to Interest Rate Risk? Economic Modelling, 39, 273-281. http://dx.doi.org/10.1016/j.econmod.2014.03.007

\section{Copyrights}

Copyright for this article is retained by the author(s), with first publication rights granted to the journal.

This is an open-access article distributed under the terms and conditions of the Creative Commons Attribution license (http://creativecommons.org/licenses/by/3.0/). 